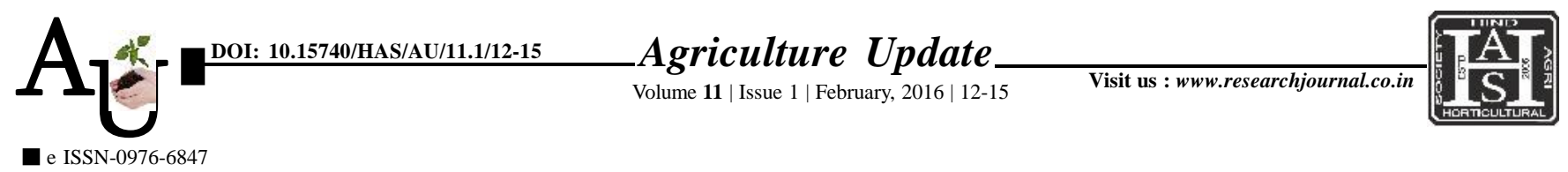

\title{
Research Article: Water use efficiency, consumptive use and soil moisture extraction pattern of wheat as influenced by irrigation schedules and genotypes
}

\author{
Article Chronicle : \\ Received : \\ 12.12.2015; \\ Revised : \\ 19.12.2015; \\ Accepted : \\ 05.01.2016
}

\section{KEY WoRds :}

Water use efficiency, Consumptive use, Soil moisture depletion pattern, Irrigation schedule, Wheat genotypes
Author for correspondence:

\section{AFZAL AHMAD}

Department of Agronomy, College of Agriculture, University of Agricultural Sciences DHARWAD (KARNATAKA) INDIA

Email: afzal_ahmad1974

@yahoo.in

\section{AFZAL AHMAD}

SUMMARY : An investigation was carried out to study the effect of irrigation schedules and wheat (Triticum aestivum L.) genotypes on yield, consumptive use of water, soil moisture depletion pattern and water use efficiency at the University of Agricultural Sciences, Dharwad (Karnataka) in the year 2001-02. The design of the experiment was split plot with three replications. The wheat crop irrigated six times $\left(\mathrm{I}_{7}\right.$ irrigation schedule) recorded significantly highest grain yield $\left(2669 \mathrm{~kg} \mathrm{ha}^{-1}\right)$ compared to other irrigation schedules. Among the wheat genotypes, DWR-1006 (durum wheat) recorded significantly higher yield (2390 $\left.\mathrm{kg} \mathrm{ha}^{-1}\right)$ as compared to DWR-162 (aestivum wheat). The maximum consumptive use $(485.5 \mathrm{~mm})$ was found with frequently irrigated treatment $\left(\mathrm{I}_{7}\right)$ while the least consumptive use was registered with $\mathrm{I}_{1}$ irrigation schedule. Similarly, among the different wheat genotypes, DWR-1006 showed higher consumptive use of water $(335.1 \mathrm{~mm})$. The maximum water use efficiency was found with $\mathrm{I}_{2}$ irrigation schedule and with DWR-162. Wheat is a surface feeder, the maximum amount of moisture was depleted in shallow depth than deeper layer of soil.

How to cite this article : Ahmad, Afzal (2016). Water use efficiency, consumptive use and soil moisture extraction pattern of wheat as influenced by irrigation schedules and genotypes. Agric. Update, 11(1): 12-15. 